\title{
INSTRUMENTS FOR REGULATION THE SYSTEM \\ OF ADAPTIVE MAN-AGEMENT DEVELOPMENT \\ OF HIGHER EDUCATIONAL INSTITUTIONS
}

\section{Hanna Kravchenko ${ }^{1}$ \\ Olha Pochuieva ${ }^{2}$}

DOI: https://doi.org/10.30525/978-9934-588-53-2-17

Abstract. The paperrepresents the results of the experimental introduction of complex qualimetric sub-models for monitoring the effectiveness of the departmental system development of a higher educational institution. It is noted that the complex consists of sub-models of management development activities for the vice-rector, the director of the department, the section, the methodical structural unit, the scientific and pedagogical worker, of submodel for determining the level of professional competence of the student/ attendee. The sub-model of development management of the department is considered a key one in a higher educational institution.

The concept of "adaptive management" is defined. Functions are distinguished that may influence the management development of higher educational institutions on the grounds of analysis of the traditional management functions and the peculiarities of adaptive management. The priority of development is emphasized to be determined within adaptive management unlike traditional one carrying out through selforganization processes. The processes of self-organization taking place in the departmental system of institutions of higher education direct its development which can be achieved through a joint goal, the development of partnership relations between all management actors, elimination of inconsistencies and divergent actions based on dialogical adaptation; cooperative overall activities which favors to identify unused reserves and

\footnotetext{
${ }^{1}$ Dr. Hab. in Pedagogy,

Associate Professor, Department of Education, Foreign Philology and Translation,

Simon Kuznets Kharkiv National University of Economics, Ukraine

ORCID: https://orcid.org/0000-0002-2156-3203

${ }^{2} \mathrm{Ph} . \mathrm{D}$. in Pedagogy,

Senior Lecturer, Department of Education, Foreign Philology and Translation,

Simon Kuznets Kharkiv National University of Economics, Ukraine

ORCID: https://orcid.org/0000-0001-6954-5197
}

(C) Hanna Kravchenko, Olha Pochuieva 
joint decision-making with the subsequent prediction of the path for further development. In view of foregoing the value of the regulation function is substantiated. Regulation is interpreted as a type of management activity aimed at eliminating deviations, failures, disadvantages, etc. in a managed system through developing and implementing appropriate measures by managing system. The purpose of regulation determines the sustainability of the institution of higher education by maintaining the necessary correlation between its various elements, timely elimination of possible deviations from the established norms in the development of management objects. In this regard the types of regulation and their role in the process of adaptive management development were explored in the higher educational institution.

The generalized results of the experimental introduction of a sub-models complex as instruments for regulation the system of adaptive management development of higher educational institutions showed a positive dynamics in the development of departments and the departmental system as a whole. The index with a low level of development decreased by $19,2 \%$, with sufficient - by $13,5 \%$, with optimal $-14,8 \%$ and with a high level of development increased by $28,3 \%$. At the same time the index of the development increased by $42 \%$ in the departmental system as a whole.

\section{Introduction}

The modern strategy of higher education development in Ukraine as a participant of the Bologna Process should take into account the global and European trends in the transformation of the fundamental nature and methods of modern higher education. Integration of Ukraine into the European Community requires radical changes in the field of higher education, which are aimed towards new values and results (Nikolayenko, Shynkaruk, 2017, p. 240).

A distinctive feature of modern management is the transition from a stable functional structure to a variable changeable target management structure. The process of management in the system of higher education is an integral part of the social management systems, and from a scientific point of view, it can be defined as the purposeful interaction of a managing and managed system in regards to regulation of the educational process in order to promote it into a higher level of development. Each individual 
pedagogical system is complex and real because it includes subsystems in its composition: institution of higher education - faculty, departments, centers, laboratories, etc. Since the functioning of the socio-pedagogical system proceeds under conditions of constant changes both in the internal and external environment then management of such a system must respond to these changes and provide its restructuring in due time.

The specificity and complexity of managing social systems including higher education institutions is determined by the need to execute two contradictory functions. The first function is to ensure the functioning of the system meaning to create conditions that provide the implementation of social functions of the system (educational, judicial, political, etc.). The basis for implementation of this management function is standards, norms, rules that may have different forms, and the general task of management is to eliminate deviations from established norms (reaction control) or to prevent possible abnormalities. The second function is to ensure the development of the system involving significant changes in the existing structure and in ties formed in accordance with established norms of activity. Therefore, the task of ensuring the system development contradicts the task of ensuring its functioning (Ryabova, 2013).

Mutual coordination of the manager and executor actions is arranged by a shift of their relations in the management process. The activity of each of them becomes variable according to the real conditions forming in the process of achieving a commonly defined real purpose. There is an arbitrary mutual adaptation of the participants in the management process, which provides self-improvement of the person, and simultaneous improvement of the environment surrounding him, and it directly leads to adaptive management.

Despite a wide range of researches belonging to scientists who develop various aspects of adaptive management of social and pedagogical systems there is still no entire, objective study of the theory and technology within adaptive management development of higher education institutions.

The first researches including elements of adaptive management of higher education appear in Ukraine in 2011. Elements of adaptive management are used in the national high school in Academician Stepan Demianchuk International University of Economics and Humanities (Rivne), The Ivan Franko National University of Lviv (monitoring the results of the educational 
process); Simon Kuznets Kharkiv National University of Economics, Uzhgorod National University (new technology of administrative control is coaching); Donetsk Polytechnic College, Kyiv Industrial College, IvanoFrankivsk State College of Technology and Business (monitoring through the results of educational activities).

\section{Theoretical basis of the study}

Adaptive management is a process of mutual influence causing the mutual adaptation of the subjects behavior activity on the dia (poly) logical basis, which is ensured by a consensual definition of a realistic goal with the subsequent combination of efforts and self-direction of actions towards its achieving (Borova, 2012). The leading feature of adaptive management is the mutual adaptation and the organic combination of the manager's goal and the pursuit of the performer based on the development of flexible models of activity (Kravchenko, 2014).

G. Yelnikova observes that adaptive management directs subjects of activity to self-management and self-development (Yelnykova, Zahika, Kravchenko, 2016). Adaptive management as well as traditional has certain functions that include: joint development of a realistic goal; criteria modeling; co-operation of actions and self-direction; process monitoring and monitoring of the result; prognostic regulation (Yelnykova, Borova, Kasianova, Poliakova, 2009).

Analyzing the functions of traditional management and the peculiarities of adaptive management, we have identified the functions that can influence development management institutions of higher education (Table 1) (Rabcheniuk, 2000).

Comparing the characteristics of the functions within traditional and adaptive management it can be argued that adaptive management determines the priority of development unlike with traditional which is carried out through self-organization processes.

The processes of self-organization taking place in the departmental system of institutions of higher education direct its development, which can be achieved through a joint goal, the development of partnership relations between all management actors, elimination of inconsistencies and divergent actions based on dialogical adaptation; cooperative overall activities, which favors to identify unused reserves and joint decision- 


\section{Performance comparison of traditional and adaptive management functions}

\begin{tabular}{|c|c|c|}
\hline No. & $\begin{array}{c}\text { Functions of traditional } \\
\text { management }\end{array}$ & $\begin{array}{c}\text { Functions of adaptive management } \\
\text { of the depart-mental system }\end{array}$ \\
\hline 1 & $\begin{array}{l}\text { Goal setting is a single programmed } \\
\text { result by the manager, which is } \\
\text { supposed to get in the process of } \\
\text { activity. «General» goals of such } \\
\text { complex systems as educational (peda- } \\
\text { gogical) are projected in general terms. }\end{array}$ & $\begin{array}{l}\text { The joint development of a realistic goal, } \\
\text { the co-ordination of the goals between the } \\
\text { departments and methodical structures } \\
\text { compiling the depart-mental system, } \\
\text { the adoption of a conscious deci-sion } \\
\text { concerning the implementation of the goals. }\end{array}$ \\
\hline 2 & $\begin{array}{l}\text { Planning by a sole leader, as a } \\
\text { result the annual plan of work of an } \\
\text { educational insti-tution does not take } \\
\text { into account the plans of the work of } \\
\text { the departments/methodical units, the } \\
\text { specifics of their activities, and the plan } \\
\text { of work of structural units in the organ- } \\
\text { ization does not take into account the } \\
\text { indi-vidual plan of work of scientific } \\
\text { and peda-gogical personnel. }\end{array}$ & $\begin{array}{l}\text { Criteria modeling, distinguishing of criteria, } \\
\text { crea-tion flexible models of the structural } \\
\text { division ac-tivity within the departmental } \\
\text { system and its management. }\end{array}$ \\
\hline 3 & $\begin{array}{l}\text { Organization is a clear division } \\
\text { of responsi-bilities by the director } \\
\text { without taking into account the } \\
\text { emerging peculiarities in the activities } \\
\text { of the structural units and its man- } \\
\text { agement. }\end{array}$ & $\begin{array}{l}\text { Co-operation of actions and self-direction, } \\
\text { elimi-nation of inconsistency and divergence } \\
\text { on the basis of dialogical adaptation; } \\
\text { co-operation of actions and self-direction } \\
\text { to achieving a common goal through the } \\
\text { development of partnerships between all actors } \\
\text { in the management process, administration } \\
\text { and subordinates (direct interac-tion within the } \\
\text { team), combining the efforts of all subsystems } \\
\text { for achieving its objectives. }\end{array}$ \\
\hline 4 & $\begin{array}{l}\text { Control is the activity of managers to } \\
\text { estab-lish the conformity of scientific, } \\
\text { educational and methodological } \\
\text { work of the educational institution } \\
\text { to national standards and norms. } \\
\text { Implementation of external monitoring } \\
\text { of educational activities (collection, } \\
\text { accounting, processing and analysis } \\
\text { of information on results for effective } \\
\text { management). }\end{array}$ & $\begin{array}{l}\text { Self-monitoring of the process and } \\
\text { monitoring of the result is the coordination } \\
\text { of external and in-ternal influences, external } \\
\text { monitoring of the man-agers at the input } \\
\text { and output; internal self-monitoring of the } \\
\text { process of tasks implementa-tion; processes } \\
\text { support of self-organization and self- } \\
\text { development of structural units within the } \\
\text { departmental system in all areas of activity; } \\
\text { ac-companying self-control the process with } \\
\text { the cur-rent adjustment. }\end{array}$ \\
\hline 5 & $\begin{array}{l}\text { Regulation is organization, } \\
\text { establishment and interacting in order } \\
\text { to bring into accordance the existing } \\
\text { system of the organization functioning } \\
\text { and to focus on the development of } \\
\text { something. }\end{array}$ & $\begin{array}{l}\text { Prognostic regulation, detection of unused } \\
\text { re-serves; inclusion the relevant criteria } \\
\text { into the model; joint decision-making and } \\
\text { joint forecasting of the path for further } \\
\text { development is prognostic regulation on the } \\
\text { result. }\end{array}$ \\
\hline
\end{tabular}


making with the subsequent prediction of the path for further development. Hence, the function of regulation requires special attention within our study.

Regulation is a type of management activity aimed at eliminating deviations, failures, disadvantages, etc. in a managed system through developing and implementing appropriate measures by managing system (Gayevskyi, 1997).

Regulation function is interpreted the most ambiguously. Not all theorists of management generally include it in the operating cycle. However, we believe that the function of regulation is intended to ensure the dynamics of the organization development, eliminate obstacles and deviations from the goals of activity.

The objective basis of the regulation function is associated with the maintenance of dynamic equilibrium. The internal and external conditions of the organization are variable. Therefore one of the head's activities of the higher education institution is connected with the creation of a balance between the traditions of the organization's functioning and its development, between the preferences of the educational services customers and the capabilities of the departments together with the methodological units to provide it, between the expectations of the team and the realities of life, etc.

The purpose of regulation determines the sustainability of the institution of higher education by maintaining the necessary correlation between its various elements, timely elimination of possible deviations from the established norms in the development of management objects.

The regulation function causes the biggest number of debates among scientists. Some of them consider regulation an independent management function; others esteem regulation as part of the control function; there are those who do not regard regulation the management function. P. Frolova considers regulation in conjunction with control and notes that the control, examination and regulation of the decision-making process are the final function of management activity (Frolov, 1988). B. Gajewski notices that regulation aligns the ratio of single process elements, which occurs during execution of the task. The scientist emphasizes the fact that the objects of management are such elements, the autonomy of which is the expression of the systemic nature of the task in the implementation of which they are interested (Gayevskyi, 1997). T. Rabchenyuk considers the essence of regulation as a basis supporting the educational process at the required 
level on the example of school management providing a basis for renewal and improvement, combining all activities of the educational institution head into a single whole (Rabcheniuk, 2000). A. Ermola, L. Moskalets, O. Suzhik, O. Vasylenko consider regulation as a support the appropriate level of organization within the educational process depending on the new socio-economic conditions; adjustments based on the analysis of the results (Yermola, Moskalets, Sudzhyk, Vasylenko, 2000).

N. Martynenko gives the following definition of regulation. Regulatory influence on the object of management makes any accepted and implemented management decision. The regulatory process represents the final stage in the adoption of a management decision - an act of inductive and practical activity of a manager, which is carried out in a pre-designed and deliberately chosen version. Regulation is a type of activity that represents the influence of the leader on subordinates in such a way that they perform work to achieve the goals of the organization. Tasks of regulation are updating of planned tasks, norms, standards in order to ensure the timely and effective achievement of the organization goals. Depending on the content of the problem (detected deviation) and the way of developing regulatory influence there are two types of regulation: reactive is carried out when the standards are not achieved and it is aimed at smoothing the deviations from the standards; feed-forward - the problem is considered as a potential oppor-tunity to improve activity or derive the greatest benefit from the presented opportunities (Martynenko, 2003).

Thus, the manager influence is possible over the object of management through the implementation of regulation to ensure its dynamic equilibrium.

Many different methods of regulation are used in the management practice of the organization every day directed to the behavior of management objects. People are an integral part of the regulation function. Therefore, regulation is a communication process between the leader and the subordinates. It is important to understand that it is possible to make a decision and achieve a positive result only by working with people (performers) and with their assistance. A relation can be settled between the subject of management and the controlled object only through a function of regulation.

In this regard, it is very important to know the types of regulation and their role in the process of adaptive development management of the higher educational institution. Let us take a closer look at it. 
The realization of certain rules, procedures and behavioral styles is the main instrument of implementation stabilizing regulation. The stabilizing influence is accomplished on the behavior of scientific and pedagogical workers of higher educational institutions in the process of educational activity and management of structural units by observing regulatory documents, its content depends on the object of management (department, section, methodological department, and laboratory), which activity is regulated and on activities types of the subject of management. For example, the Regulations on the activities of the department cover: the peculiarities of the department activity, its purpose, tasks, powers of the head, the duties of the department staff, full professors, senior lecturers, assistants professor, laboratory assistants, etc. The position description specifies the authority of a particular official. Many aspects of higher education institutions are regulated by relevant documents.

Stabilizing regulation is aimed at the regimentation of a general organizational nature. Its substance is to establish certain social rules, precise instructions for action, certain types of activities and behavior of employees throughout the organization. Its essence is the subordination of officials to rules behind the documents defining requirements for actions and compliance with specific conditions.

Administrative regulation is process of direct influence of the head over the performer. Its use is conditioned by the need to eliminate deviations from the established standards found in the control process and the intention to act for implementation the management decision. The content of administrative regulation is determined by specific causes and emerging situations. It as a rule does not have well-established patterns of appearance and time of occurrence. It is the result of emerging situations and un programmed management decisions.

Active administrative influence is manifested in orders, instructions, decrees, disposals, resolutions, and decisions. Passive administrative influence concludes informing, recommendations, suggestions, wishes. Passive forms do not possess the force of compulsory, immediate, timely and accurate response. Its main purpose is to increase the efficiency of communications in the process of implementing active regulatory influence. It often complements the active form of regulation, which increases their effectiveness. 
The content of administrative regulation is in all cases to understand the reasons for the deviation and achieve the return of the process parameters to the needed actions using the information of the control functions.

Disciplinary regulation deals with the behavioral aspects of the regulation function.

Disciplinary regulation is based on the fact that employees indirectly agree to perform it at a level satisfying the organization by performing a particular job and remunerating it. According to its content disciplinary regulation may have:

a) administrative influence. For example, an order to encourage or punish on the results of a particular employee;

b) regimenting influence. For example, a position description reflecting the results of the distribution and delegation of authority of a particular employee in the department or methodical unit;

c) normalizing influence. For example, the time limit for the development of a program-target project, etc.

Disciplinary regulation is manifested in the right of the head to demand from subordinates:

a) actual results on the identified key points being delegated to;

b) periodic progress reports;

c) detailed implementation of their instructions and the permission for freedom of action only in cases of extreme necessity;

d) literal execution of instructions and orders, immediate notification of the occurrence of any difficulties.

The leader should proceed from the fact that members of his team are obliged to adhere to labor discipline, labor legislation, regulations and requirements for the organization of work within disciplinary regulation.

Thus, the regulation function plays an active role of the link between the subject and the object of control.

In addition, the regulation can be highlighted that is being carried out within other management functions. The function of regulation differs from all the other in that the content of activities for its implementation is not planned in advance. If it was previously known what deviations could occur in the implementation of the management goal, it could be avoided during the implementation of the "organization" function. 
The organization is usually aimed at the entire team and significant management tasks and regulation - at separate structural units, at individual members of the team and more local problems. The need for regulation of all subsystems activity within the departmental system of a higher education institution can be related not only to the lack of performance quality of departments and structural methodical units but also with other reasons (change of director or employee, member of a temporary creative team/temporary creative group during preparation of measures for the next joint activity or adoption of a new scientific and pedagogical worker of the department). Due to the fact that the measures of the joint organization activities are aimed at the whole team then the leaders of the higher levels of management within the departmental system take part in their implementation. And whereas regulatory measures are focused on individual members of the team or on separate structural units, the heads of the lower levels of management as the heads of departments, heads of methodical units, heads of the temporary creative team/temporary creative group, etc., take part in its implementation (Rabcheniuk, 2000).

The content and means of regulatory activity depend on the reasons for the deviation of the current result within adaptive management of the higher educational institution from its purpose. Let us consider the most likely list of these reasons:

1.imperfection of the purpose and perspective plan of all structural subdivisions development within the departmental system of a higher educational institution;

2. poorly performing tasks of the «organization» activities function in the internal environment of departments and independent methodological units as well as in the internal environment of higher educational institution;

3.the presence of scientific and pedagogical workers and units not covered by joint activities in preparation for the implementation of a common goal;

4. changes in the external conditions of functioning and development of a higher educational institution;

5. changes in the internal conditions of functioning and development of a higher educational institution;

6. decrease in the motivation level of scientific and pedagogical workers for participation in the joint tasks execution (Kravchenko, 2015). 
People are an integral part of the regulation function. Therefore, regulation is a communication process between the leader and the subordinates. Not only the influence is carried out on a person but an influence prompting him to act directly or indirectly (through a document, norm, etc.) in the process of regulation. Regulation should be focused on the behavior of the person, and it depends on such characteristics as the perception of regulatory influence and the expectation of the consequences of this influence implementation.

It is the function of regulation ensuring the execution of current measures to eliminate deviations from the given mode of higher educational institution development. Its role is to eliminate obstacles and deviations from the set targets. It is carried out in the process of operational management of the joint activity over all structural units within the departmental system of the higher educational institution by obtaining information on the basis of qualimetric sub-models and its results analysis (Ryabova, 2013). Such a review of the regulation function is used in cybernetics. The feedback lies at the heart of it used to eliminate the effects. The need to regulate the development of a higher educational institution appears not only due to negative effects. The most frequently it is connected with the need for natural dynamic development of the organization, with the emergence of new tasks of adaptive management, with the transition of higher education to a new state under the influence of internal and external factors (Annienkova, 2012).

Higher educational institutions can flourish and resist environmental effects only if it can change its state as fast as it comes in an educational environment. Since the departmental system of a higher educational institution consisting of interrelated departments (along with structural units), self-teaching centers and departments of the Institute with mutually interdependent relationships for joint efforts to implement the tasks within the educational, methodological, scientific work is constantly in a dynamic equilibrium with the factors of the external educational environment, this process should be constantly maintained (Yermola, Moskalets, Sudzhyk, Vasylenko, 2000).

In this situation, the function of regulation should ensure timely response of all subsystems of the departmental system of the higher educational institution, which is aimed at adapting to the external environment or neutralizing its negative impact. 
In view of the foregoing one can conclude that the monitoring of the effectiveness is to watch the performance of all substructures of the higher educational institution. The nature of the monitoring elements interrelations is based on the balance of all participant interests by coordinating and directing the actions, taking into account the feedback loops, co-ordination and cooperation. And the function of regulation aimed at eliminating deviations, failures, shortcomings as a kind of management activity through the development and execution of appropriate tools in the form of a complex of sub-models.

\section{Results}

The complex consists of sub-models of activities management development for the vice-rector, the director of the department, the section, the methodical structural unit, the scientific and pedagogical worker, of sub-model for determining the level of professional competence of the student/attendees. We consider the sub-model of the development management of the department of higher educational institution as a key one and qualimetric matrix of development management within the departmental system of higher educational institution - as the resulting one (Figure 1).

Complex of activity sub-models for monitoring the DS effectiveness development of HEI

\begin{tabular}{|c|c|}
\hline $\begin{array}{c}\text { Sub-model of the vice-rector activity of } \\
\text { HEI }\end{array}$ & $\begin{array}{l}\text { Sub-model of the department director activity of } \\
\text { HEI }\end{array}$ \\
\hline $\begin{array}{l}\text { Sub-model of development management of } \\
\text { the HEI department }\end{array}$ & $\begin{array}{l}\text { Sub-model of professional growth management of } \\
\text { the scientific and pedagogical workers of HEI }\end{array}$ \\
\hline $\begin{array}{l}\text { Sub-model of development management of } \\
\text { the HEI sections }\end{array}$ & $\begin{array}{l}\text { Sub-model of educational process development for } \\
\text { students / attendees of HEI }\end{array}$ \\
\hline $\begin{array}{l}\text { Sub-model of methodical structural } \\
\text { subdivisions activity of HEI }\end{array}$ & $\begin{array}{l}\text { Sub-model of development management of the } \\
\text { departmental system of HEI }\end{array}$ \\
\hline
\end{tabular}

Figure 1. Complex of activity sub-models for monitoring the departmental system effectiveness development of a higher educational institution 
The development of a sub-model for the development management of the department is possible under conditions of qualimetric modeling of the each participant activities within the educational process of the department. The qualimetric sub-model of the department's development management is elaborated on the basis of the Law of Ukraine "On Higher Education" and "Regulations on the Department of a Higher Educational Institution" (Zakon Ukraine "Pro vyshchu osvitu", 2004).

It consists of six directions of the department activities (contingently attributes): organizational and pedagogical conditions of the department; personnel support; educational work; methodical work; research activities; consulting and marketing activity.

Each factor is specified, the criteria of its manifestation are determined according to which the evaluation of activities are carried out (Table 2).

\section{Discussion}

We proceed from the fact that in order to ensure success in achieving results it is necessary to create special conditions. These conditions characterize the possibility of a certain management structure. Consequently, the factor characterizing the activity and its result is the creation of conditions for its implementation. We defined the requirements for this activity set inside the factors as its criteria. It is specific, its criteria in each case although they are combined with the overall structure of the department (Vernydub, 2005).

The educational and methodical work of the department contains requirements, elaborated collegially and regulated at the level of the faculty/ institute. In our case, it is the development of scientific and methodological support for the teaching of educational disciplines, the level of conducting classes, conducting consultations, inter-attendance of classes and relations with other departments (Gontareva, 2015).

The requirements are established for the results of the teaching and methodological work of the department by the head of the faculty/institute and are determined for example by the coverage of disciplines by educational and methodological complexes, the introduction of new forms and methods of training, the rating of the training quality according to disciplines, etc.

The scientific work of the department is determined by the requirements for the department activities from the administration of the faculty/institute, the Ministry of Education and Science of Ukraine. This factor is manifested 
Hanna Kravchenko, Olha Pochuieva

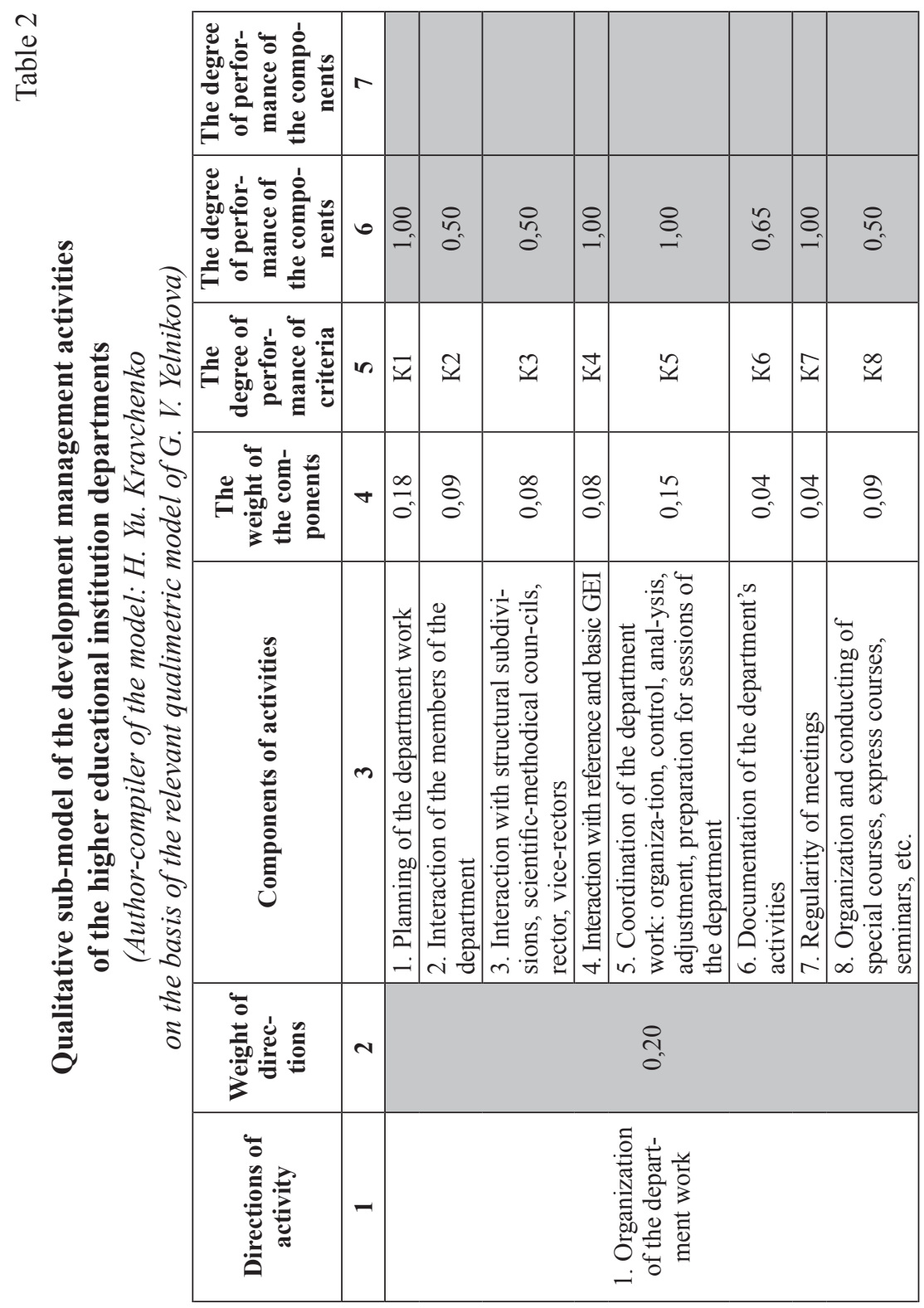




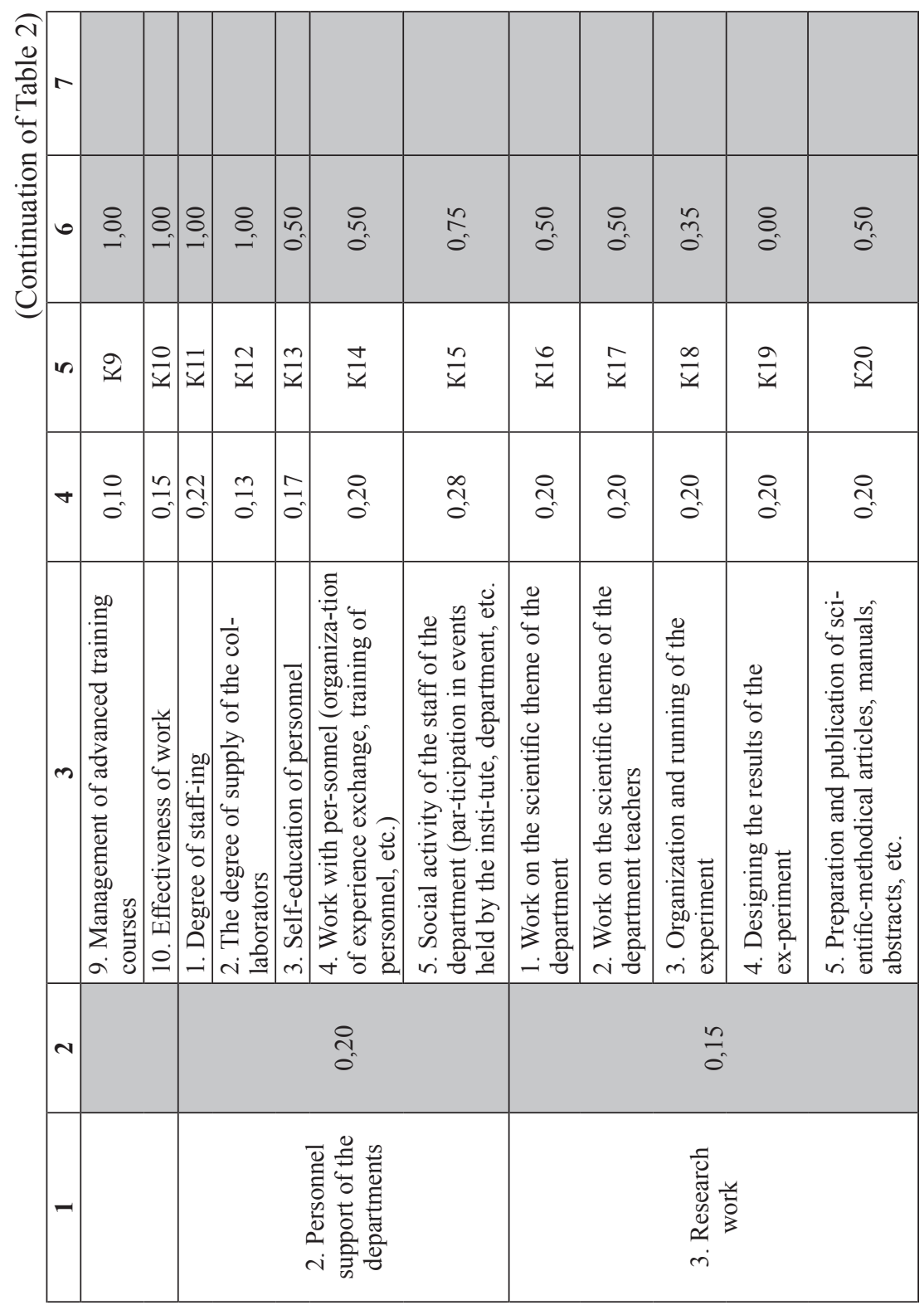




\section{Hanna Kravchenko, Olha Pochuieva}

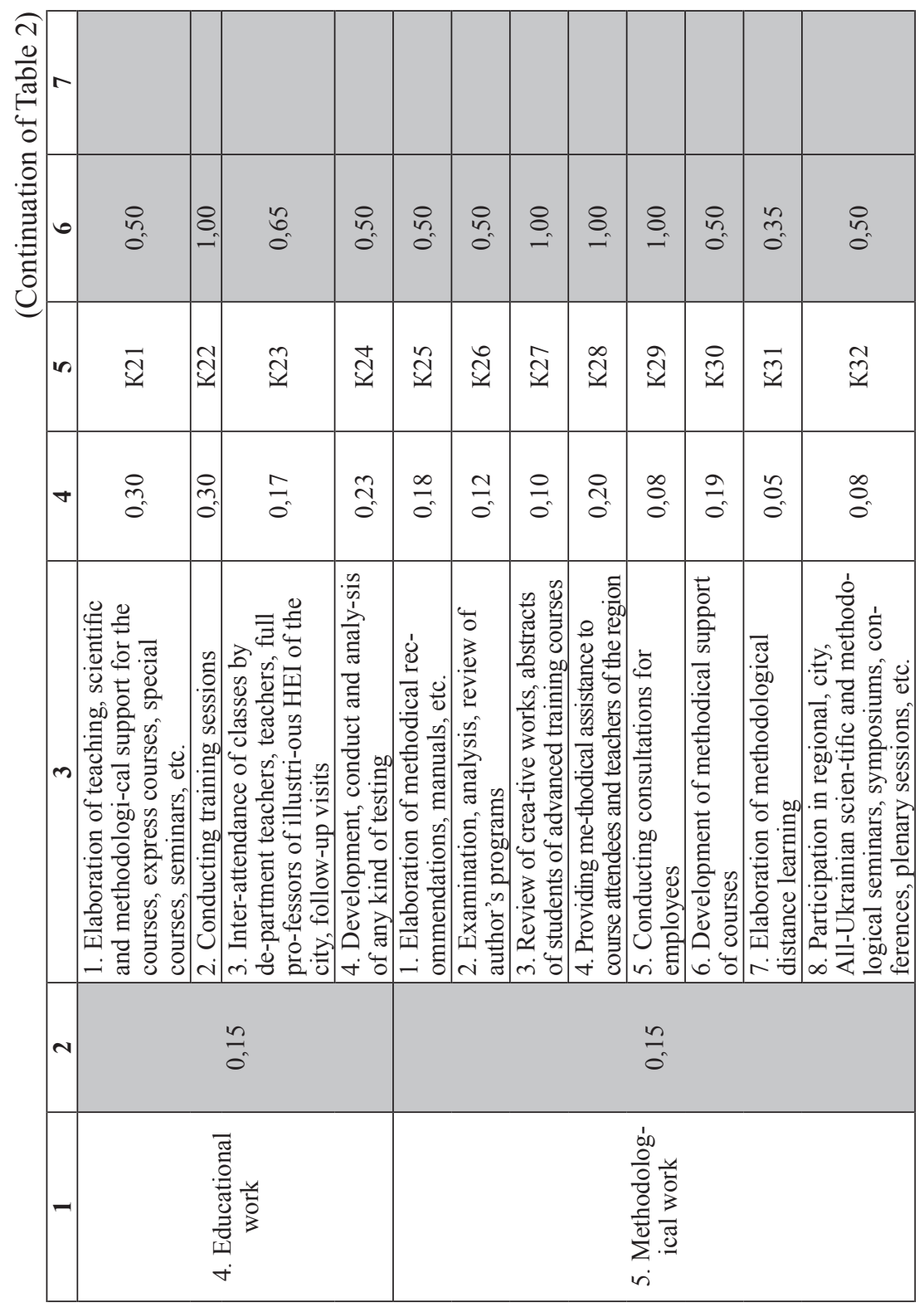




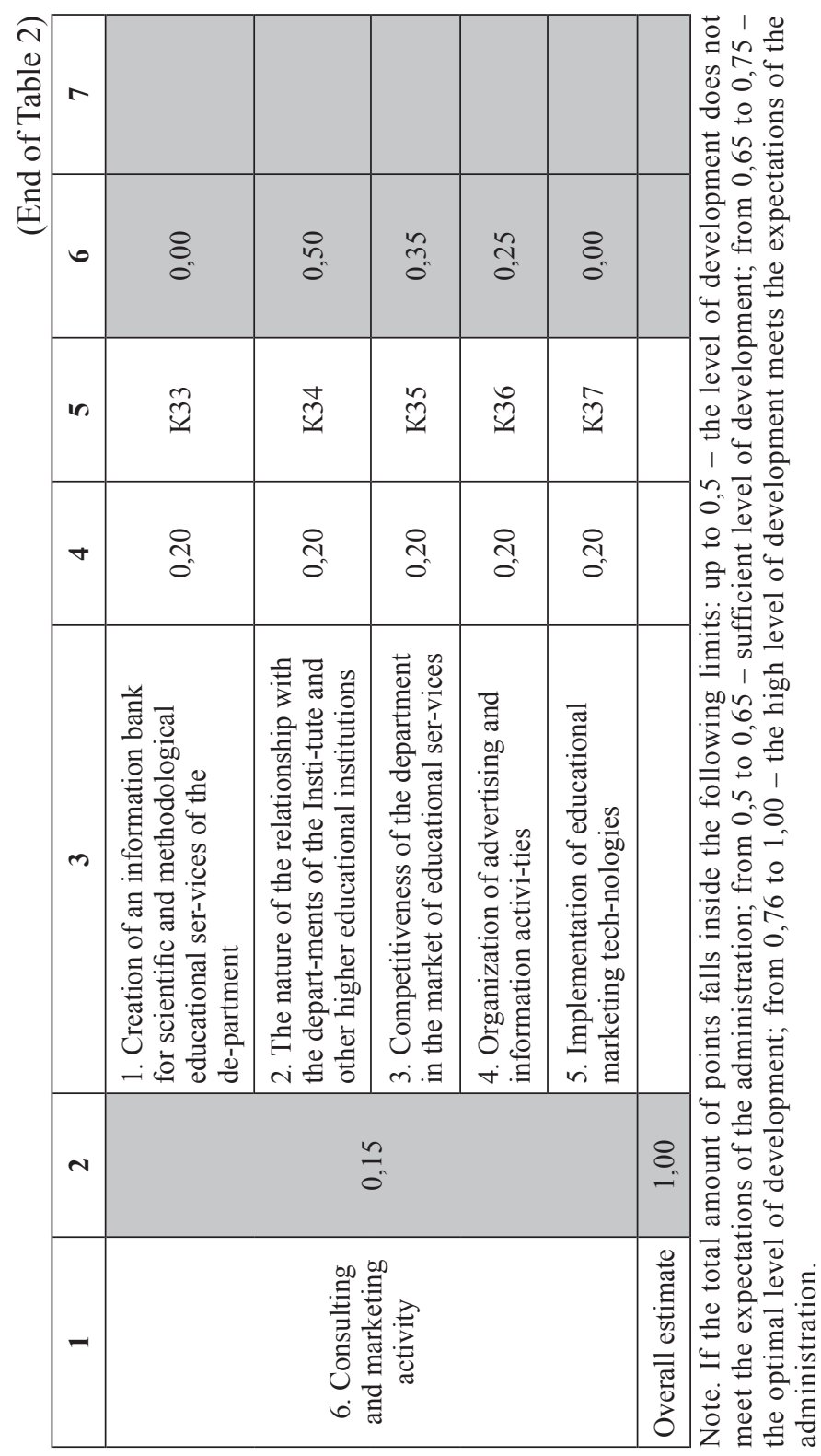


through the presence of a general scientific theme of the department, support for the implementation of regional and departmental program-targeted projects, the involvement of students/attendees into the scientific work, the availability of experimental sites, etc. Furthermore, the requirements for the publishing activity of the department are attached to the scientific work established by the administration regarding the requirements of licensing and accreditation, requirements of the Ministry of Education and Science of Ukraine. It could be the preparation and publication of scientific articles on the scientific theme of the department, monographs, scientific methodical manuals, scientific report, etc. The requirement stimulating the activity of research work is the requirement of the department participation in international, All-Ukrainian scientific projects, exhibitions and competitions, etc (Pochuieva, Kravchenko, 2018).

The human resourcing is governed by the regulations on the higher educational institution, the department and the requirements of the status of the higher educational institution. This factor can be performed through the level of personnel training activities, the level of competence and personal growth of the teaching staff, the rating of the department teaching staff among other departments, etc.

Consulting and marketing activity involves the availability of an information bank for scientific and methodological educational services; realization of the program of image activity; the implementation of educational marketing technologies and regarding the nature of the relations with the departments of other higher educational institutions (Kravchenko, 2015).

On the basis of the monitoring analysis of the intermediate results the program including corrective measures is being elaborated. The correction is carried out by all subjects of educational activity, which at the same time are the subjects of regulation.

It testifies to the presence of reflexive development of all participants in the departmental system (Table 2, Figure 2).

The obtained data from all structural subdivisions of the departmental system of the higher educational institution come into the module of adaptation and stored in the database, which has a separate drive for each subsystem with an indication of the receiving date.

Interpreting summary data department development could be directed towards the desired way, strengthening the priority aspects of the structural 
unit within the departmental system. Moreover, the achieved information provides a basis for the current regulation of the work plans of departments, sections and methodical units. This adjustment is carried out twice. The first time obtaining generalized information on the priorities of the various substructures of the departmental system (ascending and cyclic information). The second time receiving generalized data on these issues in the higher educational institution (downstream information).

Table 2

\section{Analysis of consolidated data of intermediate results monitoring the devel-opment of departments according to the directions of its activities (fragment)}

\begin{tabular}{|c|c|c|c|c|c|c|}
\hline Factors & 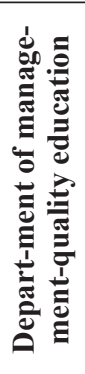 & 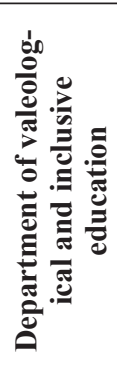 & 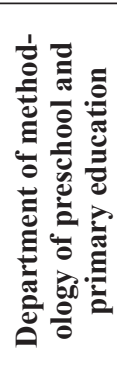 & 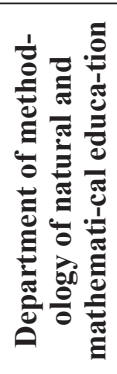 & 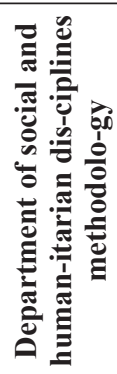 & 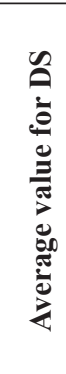 \\
\hline 1. Educational work & 0,20 & 0,22 & 0,21 & 0,23 & 0,23 & 0,22 \\
\hline $\begin{array}{l}\text { 2. Teaching and guid- } \\
\text { ing work }\end{array}$ & 0,17 & 0,16 & 0,17 & 0,20 & 0,22 & 0,17 \\
\hline 3. Scientific work & 0,19 & 0,17 & 0,11 & 0,12 & 0,10 & 0,14 \\
\hline $\begin{array}{l}\text { 4. Organizational and } \\
\text { methodical work }\end{array}$ & 0,10 & 0,12 & 0,15 & 0,14 & 0,15 & 0,14 \\
\hline 5. Human resourcing & 0,18 & 0,19 & 0,24 & 0,15 & 0,18 & 0,18 \\
\hline $\begin{array}{l}\text { 6. Consulting and } \\
\text { marketing activity }\end{array}$ & 0,16 & 0,16 & 0,12 & 0,14 & 0,12 & 0,14 \\
\hline Total & 1,00 & 1,00 & 1,00 & 1,00 & 1,00 & 1,00 \\
\hline
\end{tabular}

The generalized results of the experimental introduction of a sub-models complex showed a positive dynamics in the development of departments and the departmental system as a whole. The index with a low level of development decreased by $19,2 \%$, with sufficient - by $13,5 \%$, with optimal $-14,8 \%$ and with a high level of development increased by $28,3 \%$. 


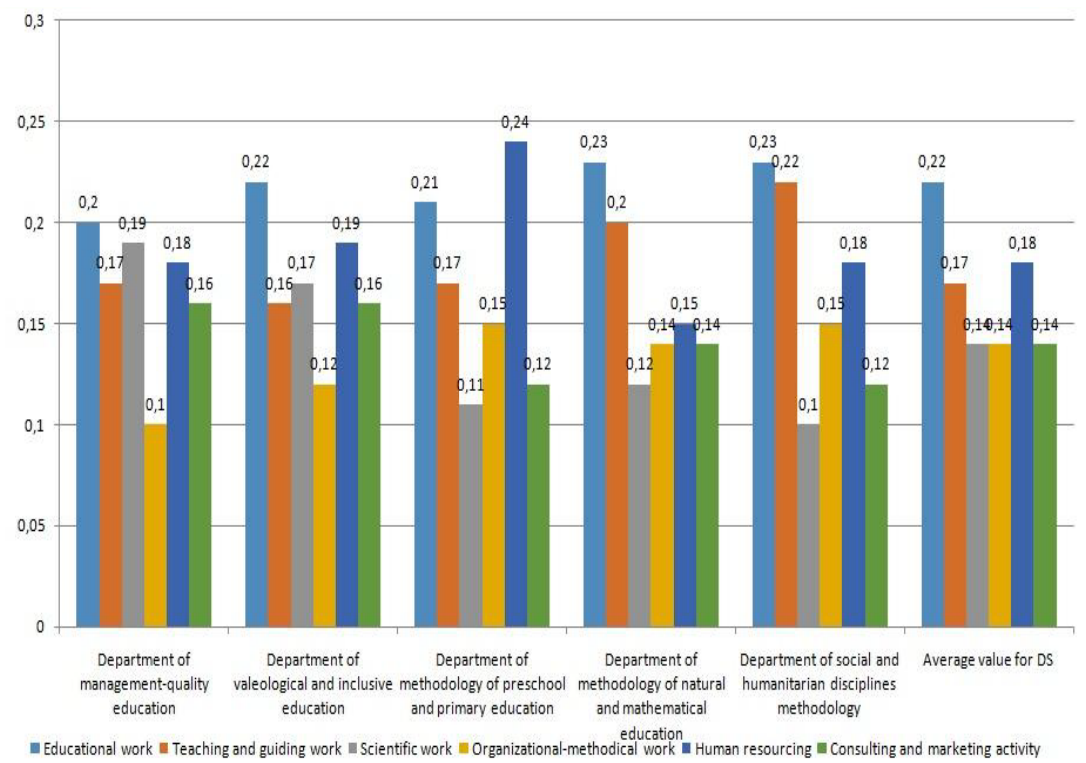

Figure 2. Analysis of intermediate results monitoring department development

At the same, time the index of the development increased by $42 \%$ of the departmental system as a whole.

\section{Conclusions}

On the basis of the theoretical principles analysis of adaptive management the was substantiated theoretical grounds of adaptive development management of the higher educational institution and it was distinguished that the specificity of the adaptive management functions promotes the development of the departmental system of the higher educational institution which is aimed at a commonly defined goal by establishing partnerships between all the subjects of management, multidirectional influences on the basis of dialogical adaptation and co-operation, which favors to identify unused reserves and joint adoption decisions on forecasting the path of further development. Taking into account the peculiarities of adaptive management development the of higher educational institutions determined 
the development of a specific marketing and monitoring instruments for managing the development of the departmental system in the form of a complex qualimetric sub-models of activity. As a part of the study we proved with qualimetric and statistical calculations that the introduction of adaptive management development of the departmental system of higher educational institutions into the management system contributes the increase of the development level of all structural divisions of the departmental system and the professionalism of managers of all administrative levels, scientific and pedagogical workers, coordinating and cooperating all subsystems of the departmental system and activates the processes of self-organization and reflexive development of its all participants.

The research does not exhaust the entire diversity of adaptive management development issues in the higher educational system. It allows you to outline problems requiring additional study. Among the other things, the issue of forming managerial competence of administration deserves attention in the context of adaptive management development of higher educational institutions.

\section{References:}

1. Annienkova, I. P. (2012). Monitoryng yakosti osvity u VNZ: kvalimetrychnyi pidhid. Vytoky pedagogichnoi maisternosti [Monitoring the quality of education in higher educational institutions: a qualitative approach]: zbirnyk naukovyh prats Poltavskogo natsionalnogo universytetu imeni V. H. Korolenka. Poltava. (in Ukrainian)

2. Borova, T. A. (2012). Teoretychni ta metodychni zasady adaptyvnoho upravlinnya profesiinym rozvytkom naukovo-pedagogichnyh pratsivnykiv vyshchogo navchalnogo zakladu [Theoretical and methodical principles of adaptive management of professional development of scientific and pedagogical workers of a higher educational establishment]. Doctor's thesis. Kiev. (in Ukrainian)

3. Frolov, P. T. (1988). Shkola molodogo direktora [School of the young director]. Moscow: Prosveshcheniye. (in Russian)

4. Gayevskyi, B. A. (1997). Osnovy nauky upravlinnya: navch. posib [Fundamentals of Management Science]. Kiev: MAUP. (in Ukrainian)

5. Kravchenko, G. Yu. (2015). Adaptyvne upravlinnya rozvytkom instytutiv pislyadyplomnoi pedagogichnoi osvity v Ukraini monohrafiya [Adaptive management of the development of institutes of postgraduate pedagogical education in Ukraine]. Kharkiv: Smugasta typohrafiya. (in Ukrainian)

6. Kravchenko, G. Yu. (2015). Kontseptualna model adaptyvnogo upravlinnya rozvytkom kafedralnoi systemy instytutu pislyadyplomnoi pedagogichnoi osvity Ukrainy [The Conceptual Model of Adaptive Management of the Development of the Cathedral System of the Institute of Postgraduate Pedagogical Education 
of Ukraine]. Massachusets Review of Science and Technologies, № 2(12), (JulyDesember), volume VI, pp. 443-448. (in Ukrainian)

7. Kravchenko, H. Yu. (2014). Vplyv adaptyvnogo upravlinnya na rozvytok kafedralnoi systemy instytutiv pislyadyplomnoi pedagogichnoi osvity [Influence of Adaptive Management on the Development of the Cathedral System of Institutes of Postgraduate Pedagogical Education]. Sbornyk materyalov Mezhdunarodnoi nauchno-praktycheskoi konferentsyi «Sotsyalno-ekonomicheskie napravleniya transformatsii gosudarstva i regionov» 29-30 avgusta, g. Lvov. (in Ukrainian)

8. Martynenko, N. M. (2003). Osnovy menedzhmenta: ucheb. posobiye dlya stud. vuzov [Fundamentals of Management]. Kiev: Karavella. (in Ukrainian)

9. Pochuieva, O. O., \& Kravchenko, G. Yu. (2018). The competency-based approach in managing the professional development of teachers of higher education institutions in Ukraine / European vector of contemporary psychology, pedagogy and social sciences: the experience of Ukraine and Republic of Poland: Collective monograph. Volume 2. Sandomierz: Izdevnieciba Baltija Publishing.

10. Ryabova, Z. V. (2013). Naukovi osnovy marketyngovogo upravlinnya navchalnym zakladom monohrafiya [Scientific fundamentals of the marketing management of the educational institution]. Kiev: Pedahohichna dumka. (in Ukrainian)

11. Vernydub, R. M. (2005). Organizatsiya i upravlinnya navchalnym protsesom $\mathrm{u}$ vyshchomu navchalnomu zakladi: navch. posibnyk [Organization and management of the educational process at a higher educational institution]. Kiev: NPU im. M.P. Dragomanova. (in Ukrainian)

12. Yelnykova, G., Zahika, O., \& Kravchenko, G. (2016). Adaptyvne upravlinnya rozvytkom profesiinoi osvity: kolektyvna monohrafiya [Adaptive management of the development of vocational education: collective monograph]. Pavlograd: IMA. (in Ukrainian)

13. Yelnykova, G. V., Borova, T. A., Kasianova, O. M., \& Poliakova, G. A. (2009). Adaptyvne upravlinnya: sutnist, kharakterystyka, monitoryngovi systemy: kolektyvna monohrafiya [Adaptive management: essence, characteristics, monitoring systems]. Chernivtsi: Tehnodruk. (in Ukrainian)

14. Yermola, A. M., Moskalets, L. G., Sudzhyk, O. R., \& Vasylenko O. M. (2000). Tekhnologiya ekspertyzy upravlinnya osvitnim protsesom u zagalnoosvitnomu navchalnomu zakladi: nauk.-metod. posib. [Technology of examination of management of educational process in a general educational institution]. Kharkiv: Poshuk. (in Ukrainian)

15. Zakon Ukrainy «Pro vyshchu osvitu» [Law of Ukraine «On Higher Education»] Retrieved from: http://zakon.rada.gov.ua/cgi-bin/laws/main.cgi?nreg $=2984-14$ (in Ukrainian)

16. Gontareva, I. V. (2015). Struktura navchal'nykh prohram pry formuvanni skladnykh kompetentnostey [Structure of curricula in the formation of complex competencies]. Scientific Bulletin of NMU, no. 1, pp. 127-132. (in Ukrainian)

17. Nikolayenko, S. M., Shynkaruk, V. D., Kovalchuk, V. I., \& Kocharian, A. B. (2017). Vykorystannya Big data v osvitn'omu protsesi suchasnoho universytetu [Using Big Data in the Educational Process of a Modern University] Information technologies and means of training, vol. 60, no. 4, pp. 239-253. (in Ukrainian) 